aparece indicado en la exposición de motivos de la nueva Ley. Un pretexto para opinar así podemos encontrar en la monopolización y no publicación de los datos y el análisis del Mapa Bibliotecario de Andalucía, requeridos desde todas partes. En tiempos donde la velocidad de las NT hubiera permitido desarrollar un debate riquísimo, la participación ha sido poco aprovechada y, además, ha despojado de calado a la intervención. En consecuencia, la nueva legislación aparece desde su gestación sin un elemento clave, como es la realidad sobre la que se legisla. EI MBA y su análisis podrian haber sido una herramienta de planificación bibliotecaria excelente y una muestra de la polifonía de lo real, verdadera riqueza de un sistema en su fase inicial de desarrollo, que otros informes ya se han atrevido a apuntar. ¿Por qué tener miedo a unos datos que expresan una realidad?

4. Estas carencias de partida dan como resultado una Ley que en general soporta una gran sombra de duda sobre ella. Ambiciosa al proponer modelos actuales, casi reglamentados en algunos casos, pero poco precisa en general en su forma de planificarlos. Puede llegar a despistar entre su deber de garantizar el derecho a la información y a la cultura a la que todos los andaluces tenemos derecho según nuestro Estatuto de Autonomía y su verdadero poder de entusiasmar en un proyecto común y de ordenar todas las parcelas del ámbito de la información. La vida se escurre del entramado de sistema que se crea. Va por otro lado y le cuesta encontrar en él cauces que optimicen sus logros.

5. Ahora han llegado nuevos tiempos que nos animan a creer que la historia no está escrita, que la hacemos entre todos. Aún con los aciertos y desaciertos de la presente Ley, hay fundadas esperanzas en la mejora. La clave está en guiar el proceso a través de la normativa de desarrollo y en saber a dónde nos dirigimos y cómo vamos a llegar hasta alli. Y sobre todo en el diálogo, en la participación, en el consenso. Son tiempos donde la interdependencia y la colaboración entre las administraciones y los diferentes agentes sociales y organizaciones serán las que resuelvan las situaciones críticas. Nos parece que es hora de trabajar juntos y encontrar la política real que nuestro sector necesita desde hace tanto tiempo. Nunca hemos faltado y estamos dispuestos a ello, pues seguimos teniendo un sueño. El de ayudar a construir una Andalucía inteligente, crítica, creativa, que está informada y sabe lo que pasa. Moderna y profundamente democrática.

Asociación Andaluza de Bibliotecarios

Asociación Andaluza de Documentalistas

\title{
Los conservadores-restauradores del arte contemporáneo alertan sobre los cambios museísticos actuales
}

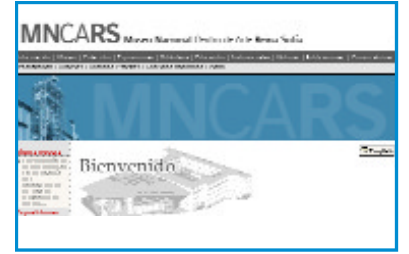

Página principal del Museo Nacional Centro de Arte Reina Sofia
Un año más, el Encuentro del Grupo de Arte Contemporáneo perteneciente al IIC Grupo Español se celebró, coincidente con ARCO, en el Museo Nacional Centro de Arte Reina Sofía. Allí se reunieron profesionales de la conservaciónrestauración y de la museología de diferentes instituciones y museos públicos y privados de todo el país, así como universitarios, alumnos de escuelas de restauración y técnicos de empresas de transporte especializado.

En líneas generales, los asistentes conveníamos en reconocer el actual momento de cambio, donde los museos están funcionando como un escaparate acelerado de propuestas y exhibiciones pero que hacen repensar su propia esencia, que existen ciertas contradicciones, como la apertura "visual" al gran público de los espacios de estudio y tratamiento de obras (en el caso de los nuevos espacios para talleres de conservación y restauración en El Prado, IVAM o MNCARS) frente a la escasa atención otorgada a los espacios de almacenaje y conservación de las obras, tanto de las colecciones como de las ex- posiciones temporales. En este sentido, lo que antaño constituía un elemento de valor añadido y de interés para especialistas y público, como eran ciertas colecciones y fondos que estructurados en torno a la idea de propuestas culturales interesaban a la comunidad, hoy son elementos problemáticos en la gestión museística y todo un reto para la conservación, accesibilidad y estudio. Incluso en algunas instituciones -conocemos casos internacionales- se está planteando la idea de la colección y de los fondos en edificios a veces muy separados de los espacios de exhibición de obras. Esto sin duda replanteará muchas de las consideraciones que hasta ahora manteníamos, pero también nos indicará hacia dónde encaminaremos los esfuerzos necesarios para aunar criterios y para realizar una buena conservación preventiva.

José Carlos Roldán

Centro Andaluz de Arte Contemporáneo 